\title{
DAMPAK INVESTASI, KINERJA EKSPOR, DAN INFLASI DALAM PENYERAPAN TENAGA KERJA INDONESIA: ANALISIS DATA PANEL
}

\author{
Siti Komariyah \\ sitikomariyah.feb@unej.ac.id \\ Halimatus Putriya \\ Fakultas Ekonomi dan Bisnis Universitas Jember \\ R. Alamsyah Sutantio \\ Politeknik Negeri Jember
}

\begin{abstract}
Employment is one of the countries development driving component. The synergy between employment and macroeconomics sectors in influencing labor market conditions is so important especially in the expansion of global economic integration which provide a major effect in the domestic socio-economic conditions. The expanding economics openness has given freedom to the investment and export sectors that have a major relation to the foreign sectors. The objectives of this research is to analyse the impact of FDI (Foreign Domestic Investment), export performance, and inflation on the labor absorption using panel data for all provinces in Indonesia. Panel data regression model is used to test these relationship which is Fixed Effect Model is the best regression model. The result shows that FDI and export performance have positive influences on labour absorption. While, inflation has a negative impact on the labor absorption. Based on these results, policy improvements are needed, both in fiscal and monetary policy. In the fiscal policy, the government could improve and optimize the infrastructure and easeinvestment regulations. While in the monetary policy, the synergy between the government and Bank Indonesia is still needed to maintain price stability and the demand that might impact on the condition of labor absorption.
\end{abstract}

Key words: FDI, exports; inflation; labor absorption.

\begin{abstract}
ABSTRAK
Ketenagakerjaan merupakan suatu komponen yang menjadi penggerak dalam pembangunan. Sinergi antara sektor makroekonomi dalam memengaruhi kondisi pasar tenaga kerja sangat penting terlebih ditengah semakin meluasnya integrasi ekonomi gobal yang memberikan efek besar dalam kondisi sosial ekonomi domestik. Keterbukaan ekonomi yang semakin meluas telah memberikan kebebasan pada sektor investasi maupun ekspor yang memiliki keterkaitan besar dengan sektor luar negeri. Penelitian ini bertujuan untuk menganalisis dampak dari FDI (Foreign Direct Investment), kinerja ekspor dan inflasi dalam penyerapan tenaga kerja dengan data panel untuk seluruh propinsi di Indonesia. Metode regresi data panel digunakan dengan model terbaik Fix Effect Model (FEM) setelah melalui pengujian pemilihan model terbaik. Hasil analisisnya menunjukkan bahwa FDI dan kinerja ekspor memberikan dampak positif signifikan terhadap penyerapan tenaga kerja. Sementara inflasi memberikan dampak negatif signifikan terhadap penyerapan tenaga kerja Indonesia. Berdasarkan hasil tersebut, direkomendasikan saran kebijakan baik dari segi fiskal melalui perbaikan infrastruktur dan peraturan pemerintah terkait kemudahan penanaman modal bagi para investor dan optimalisasi peranan infrastruktur. Selain itu, dari sisi moneter tetap diperlukan sinergisitas antara pemerintah dan Bank Indonesia dalam menjaga stabilitas harga sehingga pengendalian harga tetap dapat terjaga dan menjaga permintaan yang nantinya akan berdampak pada kondisi penyerapan tenaga kerja.
\end{abstract}

Kata kunci: FDI; ekspor; inflasi; tenaga kerja. 


\section{PENDAHULUAN}

Indonesia menjadi salah satu negara dengan jumlah penduduk tertinggi ke 4 dunia dengan jumlah penduduk 265 juta jiwa di tahun 2017 dan angkatan kerja sebesar 126,8 juta jiwa (Worldbank, 2017). Kondisi ini dapat menjadi peluang besar untuk mewujudkan pembangunan yang optimal dan menciptakan sumber pertumbuhan baru melalui peranan sumber daya manusia. Namun disisi lain, ketidak seimbangan antara permintaan dan penawaran tenaga kerja masih menjadi salah satu masalah sosial yang riskan dan penting diperhatikan. Ketimpangan yang terjadi pada pasar kerja mengakibatkan munculnya pengangguran dan menjadi salah satu penghambat pembangunan dan kesejahteraan masyarakat (Badan Pusat Statistik, 2016). Ketenagakerjaan ini harus mendapatkan perhatian yang utama sebab berkaitan langsung dengan kesejahteraan masyarakat yang dimungkinkan akan mengganggu sektor lain jika tidak ditangani dengan optimal.

Ketenagakerjaan menjadi salah satu komponen sumber daya manusia sekaligus sebagai faktor penggerak perekonomian sehingga eksistensinya memiliki peranan yang dominan dalam pembangunan. Sumber daya manusia merupakan salah satu faktor kunci dalam reformasi ekonomi, dimana suatu negara harus mampu menciptakan sumber daya manusia yang berkualitas dan memiliki keterampilan serta berdaya saing tinggi dalam persaingan global (Simanjuntak, 1998). Untuk menstabilkan pasar tenaga kerja serta meningkatkan kesejahteraan masyarakat, perlu adanya peningkatan penyerapan tenaga kerja yang diharapkan dapat berdampak pada pembangunan meliputi reduksi kemiskinan, meningkatkan kesejahteraan dan meminimalisir munculnya berbagai permasalahan sosial. Penyerapan tenaga kerja atau biasa disebut sebagai pro-job menjadi agenda penting selain membantu mereduksi kemiskinan dan meningkatkan pertumbuhan (Kuncoro, 2012). Berbagai kajian teoritis dan empiris juga banyak dilakukan dalam menyoroti permasalahan sosial ketenagakerjaan dan pengangguran. Berangkat dari pandangan teori Cobb Douglas yang menyebutkan bahwa pertumbuhan ekonomi suatu negara berasal dari peningkatan input tenaga kerja, modal, dan teknologi. Oleh karena itu, peranan tenaga kerja tidak hanya diperhitungkan secara kuantitas namun juga meliputi kualitas agar mampu menciptakan output yang optimal. Peningkatan pada output ini akan mendorong memicu peningkatan pertumbuhan ekonomi yang menjadi salah satu tolak ukur keberhasilan pembangunan suatu negara. Tingginya penyerapan tenaga kerja dengan kualitas optimal akan berdampak secara langsung pada output agregat dan pertumbuhan ekonomi sebagai cerminan dari output nasional. Oleh karena itu, pergerakan pada ketiganya biasanya selalu beriringan (Todaro dan Smith, 2003). Berbagai rangkaian kebijakan dan program telah dilakukan oleh para pengambil kebijakan untuk permasalahan menstabilkan pasar tenaga kerja. Beberapa diantaranya dari sisi internal dan eksternal. Dari sisi internal melalui peningkatan kualitas sumber daya manusia melalui investasi publik dalam rangka meningkatkan kualitas tenaga kerja melalui pendidikan dan kesehatan. Kemudian dari sisi eksternal melalui peningkatan kinerja investasi baik investasi domestik maupun mancanegara. Investasi atau penanaman model sebagai salah satu faktor yang dapat mendorong terciptanya lapangan kerja yang akan berdampak pada pengurangan permasalahan pengangguran ini juga telah diatur dalam Undang-Undang.

Menurut UU Pasal 1 No. 25 tahun 2007 tentang Penanaman Modal dapat diartikan sebagai segala bentuk kegiatan menanam modal baik oleh penanam modal dalam negeri maupun penanam modal asing untuk melakukan usaha di wilayah Indonesia. Sementara Menurut UU No. 1 tahun 1967, penanaman modal asing adalah penanaman alat pembayaran luar negeri yang tidak merupakan bagian dari devisa Indonesia 
atau alat-alat untuk perusahaan yang dimasukkan dari luar ke dalam negeri yang tidak dibiayai oleh devisa Indonesia. Kegiatan investasi terlebih dalam bentuk investasi asing ini menjadi penting bagi Indonesia dalam mendorong kinerja laju pertumbuhan ekonomi Indonesia yang dituangkan dalam kinerja pasokan modal, barang, teknologi yang berkolaborasi dalam menciptakan peluang kerja dan output (Chandra, 2006).

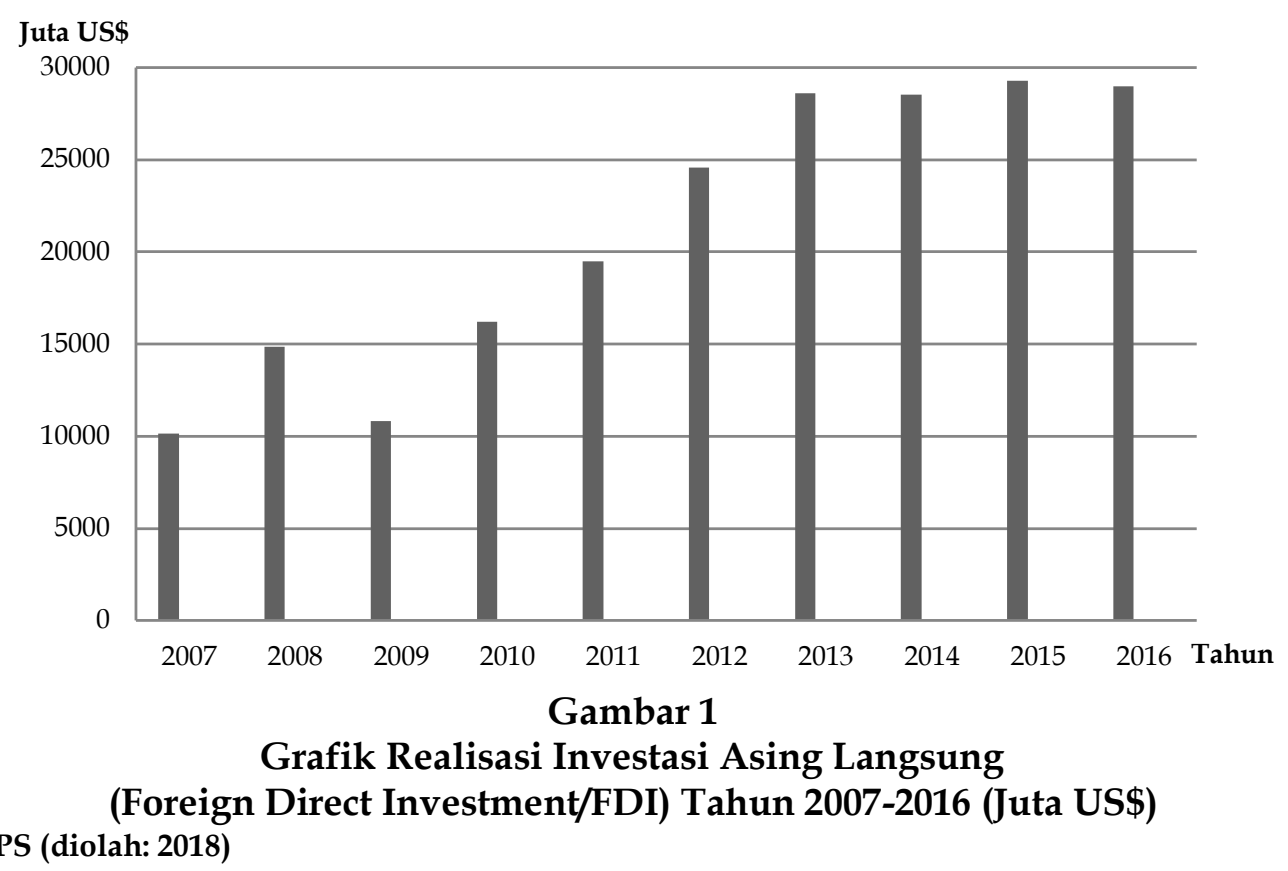

Sumber: BPS (diolah: 2018)

Gambar 1 menunjukkan pergerakan FDI Indonesia. Dari pergerakan grafiknya dapat terlihat bahwa penurunan aliran modal masuk (FDI) menurun pada 2009 yang disebabkan efek krisis ekonomi global Amerika Serikat pada tahun 2008. Hal ini terjadi karena FDI merupakan dominasi investasi terutama bagi negara-negara emerging market seperti Indonesia. Krisis global menyebabkan likuiditas dana negara-negara berkembang semakin menyusut dan menyebabkan negara-negara maju berupaya menarik investasinya di negara-negara berkembang termasuk di Indonesia. Konfigurasi perekonomian global inilah yang banyak mewarnai perjalanan ekonomi Indonesia sepanjang tahun 2009 hingga 2016. Krisis likuiditas di negara-negara maju ini menyebabkan sumber pendanaan yang menggerakkan perekonomian berkurang, dan pada gilirannya akan menyebabkan penurunan dan perlambatan pertumbuhan ekonomi. Sebagai lanjutan dari krisis global tersebut, pertumbuhan ekonomi advanced economies turun menjadi $-1.8 \%$ di tahun 2009 menurut IMF (World Economic Outlook Database, 2010). Selain itu, dampak fluktuasi ekonomi juga disebabkan oleh krisis Yunani yang mengakibatkan efek menular (contagion effect) ke negara-negara berkembang melalui 2 saluran utama. Pertama, lambatnya pertumbuhan ekonomi negara-negara maju akan menyebabkan ekspor negara-negara berkembang menjadi berkurang. Kedua, krisis likuiditas negara-negara maju menyebabkan investor di negara-negara maju menarik aliran dananya yang ditanamkan dinegara-negara berkembang, atau terjadi capital outflow di negara-negara berkembang karena negara-negara maju kesulitan likuiditas (Sriwardiningsih, 2010). Sisi permintaan dalam negeri melalui instrumen investasi menjadi penggerak utama pertumbuhan ekonomi. Tercatat bahwa pada tahun 2009 investasi hanya tumbuh 3,3\% kemudian pada 2010 berkisar antara 
8,8\%-9,3\% yang diiringi dengan perbaikan pada sektor riil (Badan Pusat Statistik, 2010).

Peranan FDI dalam perkembangan ekonomi suatu negara menjadi elemen kunci penggerak ekonomi. Disamping dapat meningkatkan kinerja produktivitas, investasi juga mampu meningkatkan pertumbuhan dan akselerasi pada beberapa elemen ekonomi lainnya. Keberadaan investasi ini berdampak pada pergerakan tenaga kerja, peningkatan kemajuan teknologi, peningkatan produktivitas yang selanjutnya akan berkontribusi pada peningkatan pertumbuhan ekonomi. Kondisi ini ditunjukkan sejak abad ke 19 hingga abad ke 20 sejak bermulanya keterbukaan ekonomi dan gencarnya globalisasi. Pada negara-negara emerging market, peranan FDI cukup dominan dalam menggerakkan sendi-sendi perekonomian melalui kegiatan perdagangan bebas, sektor perbankan, sektor produksi dan lainnya yang pada akhirnya membawa dampak positif terhadap pertumbuhan (Hady, 2001). Oleh sebab itu, eksistensi FDI ini dipercaya dapat menyelesaikan permasalahan ekonomi dan sosial. Sebagai contoh, FDI memberikan dampak positif yang kuat dalam pasar tenaga kerja dan memberikan keuntungan pada penurunan angka pengangguran di negara bersangkutan (Sidki, 2016). Aliran FDI masuk ini diharapkan dapat menciptakan lapangan kerja sehingga dapat berkontribusi terhadap upaya penurunan pengangguran dan kemiskinan serta dapat meningkatkan kesejahteraan masyarakat. Namun, kinerja FDI ini juga harus mendapat pengawasan untuk menjaga instabilitas pada pasar kerja yang riskan akan risiko yang akan berbalik merugikan perekonomian. Seperti investasi yang cenderung mengarah pada capital intensive ini tidak akan menyerap tenaga kerja meskipun efisiensi dan efektifitas produksi dapat tercapai dengan optimal (Appleyard et al., 2008).

Beberapa studi empiris juga telah memaparkan dampak kinerja FDI terhadap penyerapan tenaga kerja. Studi empiris Bande dan Riviero (2012) menunjukkan hasil bahwa guncangan yang terjadi pada per- mintaan di Spanyol lebih tinggi direspon oleh peningkatan pengangguran dibandingkan dengan investasi. Berbeda dengan studi empiris yang dilakukan oleh Rizvi dan Nishat (2009) yang menemukan bahwa FDI tidak memberikan dampak terhadap penyerapan tenaga dari tiga negara yang diteliti, yaitu Cina, India, dan Pakistan. Hanya FDI di negara Cina yang berkontribusi positif terhadap penyerapan tenaga kerja Cina. Penelitian tersebut menyimpulkan bahwa FDI tidak dapat diharapkan untuk menciptakan lapangan pekerjaan di suatu negara, sehingga diperlukan ukuran-ukuran lain untuk merangsang terciptanya suatu lapangan pekerjaan.

Distribusi investasi masih dominan terpusat diwilayah pulau Jawa, hal ini ditunjukkan oleh data dari Badan Koordinasi Penanaman Modal (BKPM) yang mengkonfirmasi bahwa sekitar 70-90\% FDI berada di pulau Jawa setiap tahunnya (Badan Koordinasi Penanaman Modal, 2016). Kondisi ini terjadi karena didorong oleh keberadaan Jawa sebagai pusat pemerintahan dan perkembangan serta tingginya jumlah penduduk yang juga sebagai akumulasi jumlah tenaga kerja terbesar berada di pulau Jawa. Pada tahun 2010 investasi tertinggi berada di wilayah Jawa dengan nilai investasi sebesar USD 11,499 milyar sementara investasi terendah adalah Maluku sebesar USD 249 juta (Badan Koordinasi Penanaman Modal, 2016). Peningkatan FDI ini juga tercermin pada perkembangan realisasi FDI yang tercatat positif di Badan Koordinasi Penanaman Modal (BKPM) sebesar 8,4\%, yaitu dari Rp 365,9 triliun menjadi Rp 396,6 triliun. Realisasi FDI ini terkonsentrasi pada sektor industri logam dasar, barang logam, mesin dan elektronik, serta sektor industri kimia dasar, barang kimia dan farmasi dengan pangsa masingmasing sektor tersebut sebesar 13,4\% dan $10 \%$ dari total FDI. Selain itu, realisasi FDI juga cukup besar ke sektor industri kertas, barang dari kertas dan percetakan (pangsa $9,6 \%$ ), sektor pertambangan (pangsa 9,5\%) dan sektor industri alat angkutan dan 
transportasi lainnya (Bank Indonesia, 2016). Penanaman modal asing (FDI) dipandang sebagai cara yang lebih efektif untuk mendorong pertumbuhan perekonomian suatu negara. Kondisi liberalisasi ekonomi yang semakin tinggi memungkinkan untuk meningkatkan kinerja FDI yang akan berkontribusi dalam menciptakan lapangan kerja sehingga dapat menurunkan angka pengangguran.

Selain melalui peningkatan kinerja FDI masuk, beberapa instrumen makro lain seperti kegiatan ekspor dan inflasi yang dapat berkontribusi dalam memengaruhi penyerapan tenaga kerja. Kinerja ekspor Indonesia mengalami trend yang menurun pada tahun 2009 sebagai akibat dari krisis global 2008. Selanjutnya, menurunnya nilai ekspor disebabkan oleh kondisi perekonomian tahun 2013 yang masih dibayang-bayangi krisis Eropa, dan melemahnya perekonomian AS serta Cina sehingga berimbas pada melemahnya permintaan ekspor Indonesia (Kemenkeu, 2013). Mesksipun terjadi penurunan dan perlambatan ekonomi global, namun kondisi perekonomian Indonesia pada tahun 2012 mampu tumbuh 6,2\%. Dari sisi sektoral, sektor padat karya yang cukup dominan menyerap tenaga kerja seperti pertanian dan industri tumbuh lebih lambat dibanding sektor padat modal seperti sektor pengangkutan dan telekomunikasi. Kondisi ini tentu menjadi tantangan bagi pemerintah dalam menstimulus kebijakan terkait penyerapan tenaga kerja (Litbang Perdagangan, 2013). Selain kinerja perdagangan melalui kegiatan ekspor, kondisi inflasi juga menjadi salah satu elemen makro yang dapat berdampak pada penyerapan tenaga kerja meskipun tidak membawa dampak secara langsung. Inflasi yang terjadi akan membawa dampak pada sisi permintaan sehingga akan memengaruhi penyerapan tenaga kerja. Dalam perspektif ekonomi, inflasi merupakan fenomena moneter dalam suatu negara dimana naik turunnya inflasi cenderung mengakibatkan terjadinya gejolak ekonomi (Silvia et al., 2013).
Dari fenomena empiris tersebut, Indonesia berada pada kondisi perkembangan investasi yang cukup membaik pasca krisis ekonomi global selama beberapa tahun terakhir. Berdasarkan hal tersebut, penelitian ini bertujuan untuk mengetahui peranan investasi, kinerja ekspor dan inflasi terhadap penyerapan tenaga kerja di Indonesia yang diproksi melalui tingkat pengangguran.

\section{TINJAUAN TEORETIS}

Arus globalisasi mengakibatkan banyak dinamika pada seluruh komponen kehidupan secara masif dan global. Pembangunan ekonomi menjadi lebih cepat, reduksi kemiskinan, peningkatan produktivitas yang diakibatkan oleh pergeseran sistem produksi dari tradisional menjadi modern dengan adanya perkembangan teknologi yang termuat dalam teori kompleksitas. Namun beberapa tokoh masih memperdebatkan teori kompleksitas ini (McMillan dan Rodrik, 2011). Integrasi globalisasi dengan adanya kemajuan teknologi yang semakin pesat ini juga memengaruhi cara bekerja. Beberapa diantaranya semakin tingginya kompetisi di pasar global yang mengarah pada penekanan pada biaya tenaga kerja dan peningkatan suatu produktivitas. Peningkatan produktivitas mengakibatkan proliferasi ekspor dan secara positif akan berdampak pada neraca perdagangan luar negeri.

Faktor produktivitas menjadi salah satu penentu pembangunan suatu negara karena kapasitas dari output produksi tersebut akan secara langsung memengaruhi pertumbuhan ekoomi suatu negara. Oleh sebab itu, peningkatan produktivitas menjadi hal yang penting dalam mendorong pembangunan dan pertumbuhan. Dalam mendorong produktivitas tersebut, diperlukan faktor pendukung seperti faktor produksi modal dan skill yang menjadi hal penting. Modal dan skill ini didukung oleh adannya investasi baik secara fisik maupun investasi sumber daya manusia yang secara tidak langsung dalam jangka panjang dapat berdampak pada kualitas dan kuantitas 
produktivitas. Oleh sebab itu, struktur pekerjaan secara tidak langsung akan berpengaruh terhadap keseimbangan perdagangan ekonomi terbuka pada jalur produktivitas. Keterbukaan pada suatu perdagangan juga dapat berdampak pada peningkatan permintaan sehingga akan berpengaruh juga pada permintaan tenaga kerja.

Beberapa hal yang dapat saling bersinergi dalam menciptakan permintaan yang berkelanjutan melalui kerjasama ekspor yang didukung oleh kualitas produksi sekaligus produktivitas yang pada akhirnya akan berdampak pada penyerapan tenaga kerja. Hal tersebut juga dapat diidentifikasi sebagai hipotesis dari pertumbuhan yang dipimpin oleh ekspor (Gozgor, 2018). Pangsa ekspor akan berdampak pada sinergi dalam negeri yang menimbulkan peningkatan permintaan dan mendorong keyakinan investasi sehingga dapat memengaruhi permintaan tenaga kerja. Investasi menjadi salah satu penggerak utama perekonomian sehingga perkembangannya memberikan dampak terhadap stok kapital yang akan berpengaruh pada penyerapan tenaga kerja. Semakin tinggi rasio kapital per tenaga kerja cenderung makin tinggi kapasitas produksi per tenaga kerja. Elemen modal yang bersumber daya investasi ini telah ditekankan oleh tokoh Neo Klasik Robert Sollow (1956). Pandangan Solow memusatkan perhatiannya tentang interaksi antara pertumbuhan penduduk (mencerminkan kondisi tenaga kerja), akumulasi kapital, kemajuan tekonologi dan output (Arsyad, 2010:88-89). Ekonom Neo Klasik menyatakan terkait penanaman modal asing (FDI) ini secara keseluruhan memberikan keuntungan bagi negara yang menerima investasi sebab dapat berdampak pada penyerapan tenaga kerja dan output agregat. Dalam rangka meningkatkan minat investor asing, pemerintah Indonesia telah melakukan berbagai upaya dengan melakukan kerjasama dan promosi baik secara bilateral maupun multilateral dengan pihak asing maupun kerjasama antara pihak swasta dengan nasional. Hal ini didukung oleh institusi resmi pemerintah yang diwakili oleh Badan Koordinasi Penanaman Modal (BKPM) sebagai badan yang bertanggung jawab dalam kegiatan penanaman modal terus mengembangkan perannya dalam menumbuhkan investasi.

Aliran masuk FDI ini juga memiliki regulasi yang diatur dalam UU Nomor 1 Tahun 1967 tentang penanaman modal asing dan dilengkapi serta disempurnakan oleh UU Nomor 11 Tahun 1970 juga tentang penanaman modal asing. UU itu didukung oleh berbagai kemudahan yang dilengkapi dengan berbagai kebijakan dalam paketpaket deregulasi. Kemudian pada tahun 2007, pemerintah menerbitkan kembalu UU Nomor 27 tahun 2007 tentang Penanaman modal asing sebagai bentuk pemberlakuan peraturan yang dilengkapi dengan beberapa kebijakan dan peraturan baru. Hal ini dimaksudkan untuk lebih menarik investasi di dalam memenuhi kebutuhan sumbersumber pembiayaan pembangunan. Sementara itu, rencana FDI yang disetujui pemerintah adalah nilai investasi proyek baru, perluasan, dan alih status, yang terdiri atas saham peserta Indonesia. Menurut Sukirno (2010) kegiatan investasi memungkinkan suatu masyarakat terus menerus meningkatkan kegiatan ekonomi dan kesempatan kerja, meningkatkan pandangan nasional, dan meningkatkan taraf kemakmuran masyarakat. Pelopor Klasik Adam Smith (17291790) melihat bahwa alokasi sumber daya manusia yang efektif adalah pemula pertumbuhan ekonomi. Setelah ekonomi tumbuh, akumulasi modal (fisik) baru mulai dibutuhkan untuk menjaga agar ekonomi tumbuh. Dengan kata lain, alokasi sumber daya manusia yang efektif merupakan syarat perlu (necessary condition) bagi pertumbuhan ekonomi.

Penelitian yang dilakukan oleh Sidki (2016) juga menunjukkan hasil bahwa FDI berpengaruh positif dan memiliki keseimbangan jangka panjang terhadap tingkat penyerapan tenaga kerja di Indonesia. Selain itu, Sjöholm (2016) menyoroti peranan FDI dalam menyerap memengaruhi nilai tambah 
dan penyerapan tenaga kerja. Dari analisisnya menunjukkan hasil bahwa FDI berpengaruh dalam meningkatkan nilai tambah sehingga akan berdampak pada peningkatan pendapatan maupun peningkatan upah tenaga kerja. Selain itu, peningkatan FDI juga dapat memberikan peningkatan pada penyerapan tenaga kerja jika terjadi peninngkatan pada permintaan barang. Sementara itu, dari sisi peranan ekspor dalam penyerapan tenaga kerja dilakukan oleh Wibowo (2013). Hasil penelitiannya menunjukkan bahwa total ekspor mengalami penurunan sebesar $6,6 \%$ dan $5,5 \%$ nya pada ekspor non migas. Penurunan sebesar 5,5\% tersebut mengakibatkan berkurangnya kesempatan kerja sebesar 549 ribu orang. Kondisi tersebut juga berakibat pada peningkatan angka pengangguran.

Investasi memiliki nilai ekonomi yang ditinjau dari penambahan output dan jumlah dari tenaga kerja yang terserap (Vanda, 2008). Investasi memiliki pengaruh yang kompleks sehingga investasi tidak hanya diharapkan mampu meningkatkan pertumbuhan melalui jumlah output yang dihasilkan namun juga untuk menyerap tenaga kerja yang akan berimbas pada penurunan angka pengangguran dan penurunan kemiskinan. Beberapa studi empiris seperti yang dilakukan oleh Greenaway et al., (2002) menunjukkan bahwa investasi modal asing pada negara berkembang ternyata memberikan dampak yang cukup positif dan masif terhadap kondisi sosial ekonomi. Dampak tersebut antara lain ditunjukkan dengan adanya peningkatan investasi yang masuk dapat menciptakan lapangan kerja sehingga ini juga akan meningkatkan pendapatan masyarakat yang nantinya juga berdampak pada peningkatan permintaan.

Ketika permintaan meningkat, maka akan meningkatkan produksi yang akhirnya berdampak pada output agregat sebagai cerminan pertumbuhan ekonomi. Dalam penyerapan tenaga kerja yang maksimal, ini akan mengurangi pengangguran dan meningkatkan kesejahteraan masyarakat. Na- mun beberapa penelitian juga memaparkan bahwa pengaruh investasi juga tergantung dari sektor mana yang dapat menggerakkan tenaga kerja yang besar sehingga dapat menciptakan lapangan pekerjaan yang besar. Misalkan pada sektor manufaktur dan industri-industri besar berbasis teknologi yang kemungkinan tidak dapat secara maksimal dapat menyerap tenaga kerja. Hal ini dikarenakan bahwa tenaga kerja dalam sektor manufaktur dan industri besar juga tergantung skill dengan keterampilan tertentu yang belum tentu dimiliki oleh banyak tenaga kerja (Vanda, 2008). Sementara itu, investasi yang mengarah pada sektor primer misalkan di Indonesia yang menjadi sektor primer atau sektor basisnya adalah pertanian dimana terdapat sub sektor seperti tanaman pangan, holtikultura, perikanan, kelautan dan kehutanan. Beberapa sektor diatas mampu menggerakkan banyak tenaga kerja sebab sebagian besar dari produksi masih dilakukan secara tradisional yang mampu menyerap tenaga kerja besar.

Berdasarkan Teori Harrod-Domar yang melekat kuat dan menekankan bahwa investasi merupakan salah satu elemen membangun produktivitas yang berakibat pada peningkatan pertumbuhan. Dalam teori Harrord-Domar menyebut bahwa investasi mengakibatkan kapasistas barang-barang modal dalam suatu perekonomian akan bertambah (Sukirno, 2010). Keberadaan investasi sangat penting untuk menunjukkan bahwa dengan adanya investasi akan menggerakkan pertumbuhan yang mantap atau steady growth sehingga dapat menggunakan seluruh modal (full emplyment) yang berlaku dalam perekonomian (Agustini dan Kurniasih, 2017).

Peranan pemerintah sangat penting dan dominan dalam mengendalikan dan memanajemen baik dalam hal pengelolaan maupun upaya meningkatkan daya tarik investor untuk menanamkan investasinya didalam negeri. Berbagai upaya ini juga akan berdampak masif sebab semakin tingginya investasi yang padat karya juga dapat meningkatkan penyerapan tenaga kerja. Be- 
berapa yang telah dilakukan dengan perbaikan kelembagaan dan sistem administrasi investasi sehingga dapat mempermudah investor dalam menginvestasikan modalnya. Selain itu, infrastrutur juga diperlukan baik infrastruktur dalam bentuk komunikasi maupun transportasi sehingga nantinya akses untuk mengembangkan investasi semakin mudah dilakukan dengan efisien dan efektif (Sandika et al., 2014).

Selain itu, kinerja ekspor juga memiliki peluang untuk membawa dampak pada permintaan sehingga akan membawa pengaruh pada penyerapan tenaga kerja. Ekspor yang memiliki daya saing tinggi dipasar akan memengaruhi permintaan ekspor sehingga ini dapat mendorong permintaan agregat diwilayah domestik untuk menghasilkan kualitas dan kuantitas ekspor yang diinginkan. Hal ini juga akan berdampak pada penyerapan tenaga kerja baik didalam perusahaan ekspor itu sendiri maupun menciptakan lapangan kerja baru berstandar ekspor untuk menunjang permintaan ekspor luar negeri. Sementara itu, kondisi inflasi juga memberikan dampak secara tidak langsung terhadap penyerapan tenaga kerja. Pada dasarnya, inflasi merupakan kenaikan harga secara umum dan terus menerus. Sementara itu, permintaan suatu barang maupun jasa sangat ditentukan oleh faktor harga. Dalam hal ini, ketika terjadi peningkatan harga pada barang-barang tertentu maka akan berdampak pada penurunan jumlah permintaan dan begitu sebaliknya ketika terjadi penurunan harga pada barang tertentu maka akan berdampak pada peningkatan permintaan barang namun hal ini tidak berlaku untuk barang kebutuhan pokok. Sebab, barang kebutuhan pokok, jumlah permintaannya tidak didominasi oleh dinamika harga yang terjadi. Secara tidak langsung, permintaan tersebut akan berdampak pada penyerapan tenaga kerja yang ada.

Pengendalian harga menjadi sebuah kebijakan moneter yang sangat sering dan setiap kali dilakukan untuk mengendalikan lonjakan harga yang terlampau besar untuk menstabilkan permintaan. Karena inflasi dapat melemahkan daya beli yang akhirnya akan menurunkan permintaan (Dharma dan Djohan, 2015). Dampak inflasi yang tidak terkendali juga dapat melumpuhkan konsumsi dan krisis produksi sehingga keberadaanya perlu adanya pengendalian yang baik. Selain itu, dalam proses produksi, inflasi juga dapat mengganggu efisiensi sebab sumber daya yang digunakan terlampau mahal dan akan berdampak pada inefisiensi produksi. Dalam kurva Phillips (1958) memaparkan tradeoff antara inflasi dan pengangguran yang kerap kali menjadi sorotan masalah. Hal tersebut kemudian dibantah oleh Friedman (1968) dan Phelps (1968) yang berpendapat bahwa tradeoff antara inflasi dan pengangguran ini hanya terjadi dalam jangka pendek saja. Konsep dari kurva phillips ini masih menjadi perdebatan sebab akan berbeda jika diberlakukan diwilayah yang berbeda akibat adanya berbagai faktor yang kompleks memengaruhi adanya permintaan. Sebagai akibat dari hal tersebut, permintaan akan tenaga kerja juga akan mengalami penurunan sehingga menghambat penyerapan tenaga kerja dan tidak memberikan solusi terhadap pengurangan pengangguran.

\section{METODE PENELITIAN}

Data yang digunakan adalah data kuantitatif berupa data panel setiap propinsi di Indonesia yang bersumber dari Badan Pusat Statistik (BPS), World Bank, Bank Indonesia, BKPM, Bappenas. Untuk menganalisis penelitian ini digunakan metode regresi dengan data panel. Model umum yang digunakan untuk mengestimasi pengaruh penanaman modal asing terhadap penyerapan tenaga kerja di Indonesia dalam penelitian ini merujuk pada hasil studi dari Matthew dan Johnson (2014) yang menganalisis tentang pengaruh foreign direct investment terhadap penciptaan lapangan kerja di Nigeria. Model yang digunakan dalam penelitian ini adalah sebagai berikut:

$$
\mathrm{EMP}=\beta_{0}+\beta_{1} \mathrm{FDI}+\beta_{2} \mathrm{EXP}+\beta_{3} \mathrm{INF}+\mathrm{u}
$$


Dimana EMP merupakan Penyerapan Tenaga Kerja (Juta Jiwa) sebagai variabel dependen; FDI merupakan penanaman Modal Asing (Juta \$); EXP merupakan ekspor (Juta Dolar AS); INF merupakan Inflasi (dalam satuan \%) dan ketiganya sebagai variabel independen; $\beta_{0}$ adalah konstanta; $\beta_{1}, \beta_{2}, \beta_{3}$ merupakan koefisien regresi dan e merupakan error term.

Penelitian ini menggunakan metode analisis regresi berganda dengan data panel sesuai ketersediaan data yang terdiri dari beberapa provinsi di Indonesia. Dalam analisis regresi menggunakan data panel, terdapat pemilihan model terbaik sebelum dilakukan estimasi lebih jauh pada data yang digunakan. Menurut Greene (2012: 343) menyebutkan data panel itu suatu gabungan dari data time series dan cross section dan memiliki kelebihan untuk melihat dinamika fenomena yang mengkibatkan perubahan besar pada model (Greene, 2012: 496). Selain itu, data panel ini memiliki keunggulan karena peneliti dapat memperoleh fleksibilitas yang tinggi dalam membentuk suatu permodelan. Terdapat 3 permodelan pada data panel yang terdiri dari Pooled Least Square (PLS), Fixed Effect Model (FEM) dan Random Effect Model (REM). Ketiga model tersebut kemudian dilakukan pemilihan model terbaik.

Tahapan dalam pemilihan model dilakukan pengujian pada model PLS dan FEM dengan melakukan uji Chow, sedangkan untuk pemilihan antara FEM dan REM dilakukan uji Hausman sedangkan untuk pemilihan antara model REM dan PLS dilakukan uji Lagrange Multiplier (uji LM). Hasil dari pemilihan model ini dapat dilihat dari nilai probabilitas F pada uji Chow. Jika F probabilitas lebih kecil dari nilai alfa 5\%, maka model terbaik adalah FEM. Kemudian, pada uji Hausman dilihat dari nilai probabilitas cross section random, jika probabilitas lebih besar dari alfa 5\%, maka model terbaik yang digunakan adalah REM.

Sementara itu pada uji Lagrange Multiplier dilihat dengan menggunakan nilai probabilitas Breush Pagan (BP Test), jika nilai lebih kecil dari alfa 5\% maka model terbaik adalah PLS.

\section{ANALISIS DAN PEMBAHASAN}

Tujuan dilakukannya pemilihan model adalah untuk mengetahui model terbaik yang akan digunakan dalam mengestimasi pengaruh variabel dengan menggunakan common effect (pooled regresiion), fixed effect, atau random effect. Pemilihan model estimasi yaitu menggunakan uji chow, uji hausman, dan uji LM. Dari hasil analisis, ditunjukkan bahwa model terbaik ditunjukkan oleh model FEM melalui uji Chow. Berdasarkan Tabel 1 menunjukkan hasil Chow Test dengan nilai probabilitas chi-square 0,0000 kurang dari nilai alfa $5 \%(0,05)$ maka model yang digunakan adalah fixed effect.

\section{Tabel 1}

\section{Hasil Uji Chow}

\begin{tabular}{lc}
\hline \hline \multicolumn{1}{c}{ Effect Test } & Probabilitas \\
\hline Cross Section F & 0,00001 \\
Cross Section C-Square & 0,00118 \\
\hline
\end{tabular}

Sumber : Data , diolah: 2018

Berdasarkan analisis penelitian ini dengan menggunakan 330 observasi yang terdiri dari data cross section yang mencakup 33 provinsi dan data time series sebanyak 10 tahun. Berdasarkan hasil uji chow, ditemukan bahwa model terbaik adalah FEM. Hasil ini dikonfirmasi dengan nilai probabilitas pada cross section F sebesar 0,00001 lebih kecil dari alfa 5\%. Selanjutnya, untuk mengestimasi lebih lanjut, maka model yang digunakan adalan FEM.

Berdasarkan Tabel 2, menunjukkan hasil analisis regresi data panel dalam penelitian bahwa variabel-variabel independen yang terdiri dari PMA, ekspor dan inflasi dalam penelitian ini memiliki pengaruh signifikan terhadap penyerapan tenaga kerja di Indonesia. Hasil Tabel 2 dapat diinterpretasikan bahwa FDI memberikan pengaruh positif signifikan terhadap penyerapan tenaga kerja di setiap propinsi di Indonesia ditunjukkan dengan angka probabilitas kurang dari alfa 
$5 \%$ dan koefisien sebesar 264,5264. Angka tersebut berarti ketika terjadi kenaikan FDI sebesar \$1.000.000 maka akan meningkatkan penyerapan tenaga kerja sebesar 264.526.400 orang dan sebaliknya. Kemudian, kinerja ekspor juga memberikan pengaruh positif terhadap penyerapan tenaga kerja di Indonesia ditunjukkan dengan nilai koefisien 34.24156 dan nilai probabilitas kurang dari alfa 5\%. Berarti ketika terjadi kenaikan ekspor sebesar $\$ 1.000 .000$ maka akan meningkatkan penyerapan tenaga kerja sebesar 34.241.560 orang dan sebaliknya. Sementara variabel inflasi memberikan pengaruh negatif signifikan terhadap penyerapan tenaga kerja di Indonesia. Hasil ini dikonfirmasi dengan nilai koefisien sebesar -12077.32 dan nilai probabilitas kurang dari alfa 5\% yang berarti ketika terjadi kenaikan inflasi maka akan menurunkan penyerapan tenaga kerja sebesar 12077.32 orang dan sebaliknya.

Tabel 2

Hasil Analisis Regresi Data Panel dengan FEM

\begin{tabular}{ccccc}
\hline Variable & Coefficient & Std. Error & t-Statistic & Prob. \\
\hline FDI & 264.5264 & 20.29370 & 13.03490 & 0.0000 \\
EXP & 34.24156 & 6.540240 & 5.235520 & 0.0000 \\
INF & -12077.32 & 4110.609 & -2.938084 & 0.0036 \\
\hline
\end{tabular}

Sumber : Data, diolah: 2018

Dalam teori Cobb Douglas telah menjelaskan bahwa pertumbuhan ekonomi suatu negara berasal dari peningkatan input tenaga kerja, modal, dan teknologi sehingga pertumbuhan menjadi salah satu indikator penting untuk melihat prospek dan kinerja pembangunan. Hal ini juga dapat memicu pada peningkatan dan pertumbuhan pada sektor-sektor lain seperti sektor riil, sektor perbankan, sektor produksi dan sebagainya. Sisi permintaan dari output produksi akan memberikan dampak pada permintaan sektor lain seperti permintaan pada pasar barang, pasar tenaga kerja dan pasar keuangan sehingga elemen-elemen tersebut saling bersinergi menciptakan pertumbuhan yang masif (Smith, 2003). Kinerja produksi ini melibatkan elemen-elemen yang saling bersinkronisasi dalam mekanisme pasar. Peningkatan permintaan produksi ini akan berpengaruh pada permintaan tenaga kerja sehingga akan membantu meningkatkan angka penyerapan tenaga kerja. Hal ini kerap terjadi pada negara-negara dengan volalitas pergerakan permintaan yang tinggi seperti negara-negara dengan komponen penduduk yang tinggi seperti negara Indonesia. Berbagai lembaga telah memprediksi bahwa Indonesia akan menjadi negara maju pada tahun 2030 yang masuk kedalam lima besar kekuatan ekonomi dunia dengan tingkat pendapatan per kapita sebesar US\$ 18.000 per tahun. Prediksi tersebut didasarkan pada berbagai elemen seperti kinerja ekonomi Indonesia yang semakin baik dan menguat dibeberapa tahun terakhir ini dibalik melemahnya ekonomi global. Bahkan di tahun 2016-2018 pertumbuhan ekonomi Indonesia mampu tumbuh diatas pertumbuhan ekonomi global (Bank Indonesia, 2018).

Selain hal itu, komponen penduduk Indonesia yang mengalami transisi demografi yang ditunjukkan dengan perubahan struktur umur juga memberikan peluang besar untuk Indonesia menjadi negara maju. Proyeksi kependudukan Bappenas (2013), BPS (2013) dan UNDP (2012) menyatakan bahwa pada 2025-2030 Indonesia akan memperoleh peluang demografi dimana penduduk usia produkstif akan mendominasi struktur usia sehingga akan memberikan peluang untuk meningkatkan output produksi yang akan berdampak pada perekonomian. Peningkatan pertumbuhan penduduk Indonesia hingga 2030 diprediksi 
akan mencapai $0,95 \%$ per tahun dimana $52 \%$ merupakan penduduk usia produktif. Kondisi ini mengindikasikan bahwa perlu penyediaan lapangan kerja yang diharapkan mampu berkontribusi dalam pasar kerja dan menyerap tenaga kerja (Junaidi, 2016).

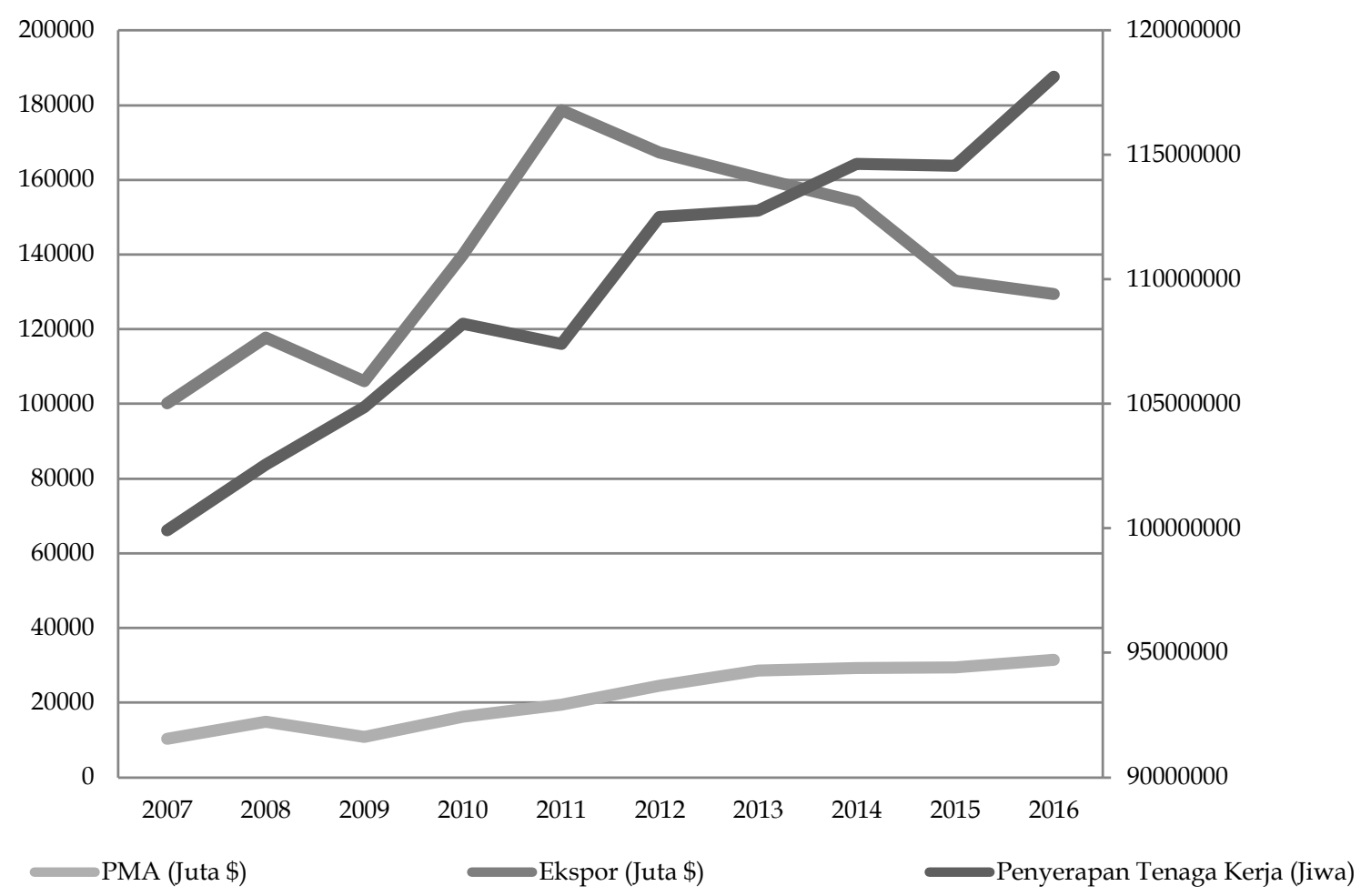

Gambar 2

Penyerapan Tenaga Kerja di Indonesia

Sumber: BPS dan BKPM, 2018: diolah

Gambar 2 menunjukkan pergerakan penyerapan tenaga kerja di Indonesia pada tahun 2009 mengalami peningkatan sebesar 2.317.913 jiwa dari tahun sebelumnya sehingga menjadi 104.870 .663 jiwa. Pergerakan PMA atau FDI dan ekspor sejalan dengan pergerakan penyerapan tenaga kerja pada tahun 2007 hingga 2010. Pada 2009 terjadi trend yang menurun pada ketiga komponen tersebut, namun penurunan pada nilai ekspor cenderung lebih tajam dibandingkan dengan FDI dan penyerapan tenaga kerja. Selanjutnya pada 2011 ekspor menunjukkan trend yang cenderung meningkat namun tidak diimbangi dengan kenaikan penyerapan tenaga kerja sementara FDI cenderung bergerak stabil. Disisi lain, kinerja ekspor Indonesia pada 2014-2016 yang cenderung mengalami penurunan akibat dari perlambatan perekonomian global (Bank Indo- nesia, 2016) namun kinerja PMA tetap berada pada kondisi yang stabil dengan trend yang cenderung meningkat. Sementara itu, penurunan ekspor juga tidak membawa dampak negatif terhadap penyerapan tenaga kerja, justru pada rentan waktu tersebut, penyerapan tenaga kerja Indonesia mengalami kenaikan jumlah hingga akhir tahun 2016 (Badan Pusat Statistik, 2017). Hal ini terjadi karena struktur usia penduduk pada tahun-tahun tersebut berada pada fase puncak penduduk usia produktif.

Indonesia sebagai negara berkembang, penanaman modal asing di Indonesia memiliki peranan yang vital dalam perkembangan dan pertumbuhan ekonomi negara. Kondisi ini dapat dilihat pada beberapa dekade terakhir dimana perdagangan bebas memicu pertumbuhan FDI dan memberikan 
dampak positif untuk pertumbuhan ekonomi negara berkembang (Dinh et al., 2019). Sehingga FDI ini memberikan dampak signifikan dalam menciptakan pertumbuhan lapangan kerja dan pertumbuhan ekonomi. Dalam beberapa tahun terakhir menunjukkan bahwa FDI memberikan dampak positif dalam mendorong penyerapan tenaga kerja Indonesia yang ditunjukkan dengan kenaikan FDI diiringi dengan peningkatan penyerapan tenaga kerja. Kinerja FDI ini juga didukung oleh kondisi internal dari keputusan pemerintah seperti situasi politik dalam negeri sebagai salah satu dukungan pemerintah terhadap investor asing (Sidki, 2016). Indonesia sebagai negara emerging market masih membutuhkan peningkatan FDI untuk meningkatkan produktivitas sehingga dapat menstabilkan berbagai sendi perekonomian untuk menjaga stabilitas ekonomi. Tercatat bahwa kinerja FDI semakin menunjukkan peningkatan yang cukup signifikan karena perekonomian Indonesia mampu menunjukkan kinerja terbaiknya selama perlambatan ekonomi global yang terjadi. Perlambatan ekonomi global yang terjadi ternyata tidak memberikan dampak buruk bagi Indonesia, bahkan dikisaran tahun 2016-2018 pertumbuhan ekonomi Indonesia mampu tumbuh diatas ekonomi dunia. Hal ini yang mendorong investor semakin yakin untuk melakukan investasi di Indonesia.

Urgensi peranan FDI terhadap perekonomian ini juga telah mendorong pemerintah untuk melakukan berbagai kebijakan baik kebijakan moneter maupun fiskal. Kebijakan moneter yang dilakukan salah satunya dengan menaikkan suku bunga investasi agar minat investor semakin tinggi untuk menanamkan modalnya di Indonesia. Selain itu, berbagai perbaikan di sektor riil yang secara konsisten dijalankan oleh pemerintah juga memberikan kontribusi signifikan dalam perbaikan iklim investasi. Keberhasilan dalam menciptakan iklim investasi yang lebih kondusif juga akan memberi dampak positif lain, yaitu membaiknya aliran masuk modal asing global masuk ke Indonesia yang pada gilirannya diprakirakan dapat menyerap tenaga kerja dan turut membawa inovasi maupun teknologi baru. (Sriwardiningsih, 2010). Selain itu, pajak dan perijinan sebagai instrumen kebijakan fiskal juga diterapkan khusus untuk investor agar mempermudah dan memberikan keuntungan bagi investor. Peran pemerintah dalam melakukan recovery perekonomian pasca krisis ekonomi global pada tahun 2008 menunjukkan hasil yang signifikan yakni penanaman modal asing mengalami peningkatan sebesar 5399.4 juta dolar AS sehingga menjadi 16214.8 juta dolar AS pada tahun 2010. Keberhasilan yang dicapai oleh pemerintah dalam mengambil kebijakan secara total keseluruhan terus mengalami peningkatan setiap tahunnya, meski masih ada beberapa provinsi yang mengalami penurun nilai penanaman modal asing sepanjang tahun 2010 hingga 2016 (Bank Indonesia, 2017).

Sementara itu, kinerja ekspor cenderung menunjukkan trend yang fluktuatif disepanjang tahun penelitian. Gambar 2 mengkonfirmasi pertumbuhan ekspor sampai 2007 mampu mencapai 17,51\% seperti yang ditargetkan pemerintah hingga tahun 2008 kumulatif ekspor telah mencapai 117.795,90 juta dollar, dibanding tahun sebelumnya hanya mencapai 100.130,50 juta dolar. Hasil tersebut menunjukkan bahwa telah terjadi peningkatan nilai ekspor dari tahun 2007 ke tahun 2008 sesuai target. Semantara itu, tahun 2009, nilai ekspor menunjukan penurunan trend dengan nilai mencapai $106.129,30$ juta dolar (turun sebesar 11,09\%) dibanding ekspor pada tahun 2008. Penurunan ini dipicu oleh penurunan ekspor non migas pada 2008 yang meliputi penurunan pada bahan bakar mineral sebesar US\$232,2 juta akibat penurunan harga minyak dunia (World Economic Outlook, 2009). Kemudian pada 2010 hingga 2011 nilai ekspor menunjukkan peningkatan dari tahun 2010 sebesar 139.938 juta dolar kemudian pada tahun 2011 sebesar 178, 691.40 juta dolar. Selanjutnya terjadi penurunan kembali trend nilai ekspor dari tahun 
2012-2016 akibat pelemahan ekonomi global terutama kinerja ekonomi China dan Amerika Serikat yang berdampak pada ekonomi dunia termasuk Indonesia.

Perbedaan komparatif dan kompetitif yang terjadi antar negara menjadi dasar adanya perdagangan internasional. Sehingga dalam hal ini, setiap negara harus saling melengkapi kebutuhan yang negara lain tidak memiliki sumber daya tersebut baik dalam bentuk barang maupu jasa. Namun, seiring dengan kebebasan tersebut, harus ada pengendalian agar barang-barang yang masuk tidak akan membawa dampak negatif bagi negara tujuan ekspor. Salah satu bentuk pengendalian perdagangan tersebut antara lain hambatan yang diberlakukan untuk membatasi barang yang masuk terlebih dalam hal impor. Dalam hal ekspor, juga diberlakukan kebijakan-kebijakan yang mendukung pelaku domestik untuk melakukan inovasi. Beberapa kebijakan yang diintegrasikan pemerintah dalam perdagangan internasional baik dari sisi ekspor dan impor antara lain hambatan tarif dan non tarif untuk impor dan berupa promosi dan diverisifikasi produk untuk mendorong ekspor (BP2KP, 2014). Beberapa kebijakan tersebut diantaranya terkait dengan promosi ekspor dan diversifikasi produk untuk ekspor untuk menunjang daya saing dipasar global.

Kinerja perdagangan internasional ini selain berdampak dalam penyerapan tenaga kerja dari sisi kinerja ekspor yang baik juga berdampak pada transaksi berjalan. Semakin besar nilai ekspor maka akan memengaruhi kinerja neraca transaksi berjalan. Selain itu juga dapat memberikan dampak pada peningkatan negara melalui cadangan devisa yang dihasilkan dari kinerja ekspor.

Berdasarkan diskusi dan hasil diatas, Gambar 2 mengkonfirmasi hasil penelitian ini bahwa peningkatan kinerja FDI selalu diikuti dengan kenaikan penyerapan tenaga kerja selama periode penelitian. Sementara itu, kinerja ekspor juga menujukkan pola yang serupa dan berkontribusi terhadap penyerapan tenaga kerja peningktan ekspor pada 2011 justru tidak diikuti oleh penyerapan tenaga kerja yang menunjukkan trend turun. Konfirmasi dari hasil penelitian ditunjukkan dengan angka koefisien dan signifikan FDI yang menunjukkan pengaruh positif dan signifikan terhadap penyerapan tenaga kerja di Indonesia sebesar 264.5264 dan nilai probabilitasnya sebesar 0,0000 yang lebih kecil dari $a=0,05$, dan bermakna bahwa setiap kali penanaman modal asing mengalami peningkatan sebesar koefisien 264.5264, maka penyerapan tenaga kerja mengalami peningkatan. Selanjutnya, ekspor menunjukkan tanda positif dan signifikan terhadap penyerapan tenaga kerja di Indonesia dengan nilai koefisien regresi variabel ekspor sebesar 34.24156 dan nilai probabilitasnya sebesar 0,0000 yang lebih kecil dari $a=0,05$, berarti setiap kali ekspor mengalami peningkatan sebesar koefisien 34.24156, maka penyerapan tenaga kerja mengalami peningkatan.

Beberapa studi empiris juga mendukung hasil penelitian ini baik dari sisi objek dan fokus penelitian. Penelitian Sidki (2016) bahwa penanaman modal asing berpengaruh positif dan signifikan terhadap penyerapan tenaga kerja di Indonesia. Hasil yang selaras juga ditunjukkan oleh penelitian Appleyard et al. (2008) yang menunjukkan adanya potensi keuntungan dengan adanya FDI yang masuk akan menurunkan angka pengangguran. Sementara itu, dari objek lain yang dilakukan beberapa peneliti di beberapa negara seperti studi empiris pada negara berkembang yang dilakukan di Zimbabwe oleh Mupfawi dan Tambudzai (2015) menunjukkan simpulan bahwa dalam jangka panjang, FDI memberikan kontribusi positif signifikan terhadap penciptaan lapangan kerja yang dapat meningkatkan penyerapan tenaga kerja. Sama halnya dengan studi empiris Çolak dan Alakbaro (2017) yang melakukan penelitian dengan subjek negara-negara persemakmuran. Hasil analisisnya menunjukkan bahwa terdapat hubungan jangka panjang yang positif antara FDI dan penyerapan tenaga kerja di negara-negara persemakmu- 
ran. Peranan pengeluaran investasi merupakan kontributor penting bagi pertumbuhan ekonomi dan lapangan kerja (Craigwell, 2006). Selain itu, Craigwell (2006) juga melakukan penelitian pada negara Karibean tentang hubungan FDI dan lapangan pekerjaan. Hasil analisisnya mengkonfirmasi bahwa peranan FDI yang masuk ke negara Karibean memberikan dampak yang signifikan dalam menciptakan lapangan kerja. Studi empiris juga dilakukan oleh Rizvi dan Nishat (2009) dengan objek negara India, China dan Pakistan dengan menggunakan uji kointegrasi. Hasil analisisnya mengindikasikan bahwa dalam jangka panjang, peranan FDI inflow memberikan dampak signifikan dalam menciptakan lapangan kerja sehingga berpengaruh pada tingkat penyerapan tenaga kerja. Kemudian, dari konten peran perdagangan (ekspor) dalam memengaruhi penyerapan tenaga kerja didukung oleh studi yang dilakukan oleh Sumpena (2018) yang mengkonfirmasi hasil bahwa adanya liberalisasi perdagangan terlebih karena peningkatan ekspor maka akan berdampak pada peningkatan penyerapan tenaga kerja.

Perkembangan aliran investasi di Indonesia menagalami dinamika yang cukup terlihat. Pada awal tahun 2018, Indonesia dominan terjadi aliran modal keluar (outflow) yang cukup besar. Namun, diakhir tahun 2018 tepatnya pada November 2018, aliran modal masuk (inflow) melaui Surat Berharga Negara (SBN) mengalami peningkatan mencapai Rp. 14,1 triliun (Media Keuangan, 2018). Selain itu, pada bulan November juga terdapat aliran modal masuk bersumber dari modal asing yang masuk dalam saham sebesar Rp. 5,5 Trilliun. Kondisi ini mengindikasikan bahwa kepercayaan asing di Indonesia masinh tinggi sehingga mereka yakin menanamkan modalnya kedalam negeri yang tentunya dapat membawa dampak positif bagi ekonomi domestik Indonesia.

Kepercayaan asing mulai meningkat yang ditunjukkan dengan peningkatan investasi dari pihak asing yang masuk dalam aliran modal masuk Indonesia beberapa tahun terakhir. Dalam menanggapi hal ini, pemerintah lebih optimis dalam mendorong dan memasukkan modal asing lebih besar termasuk investasi langsung. Meskipun pada periode kuartal ketiga 2018 terdapat penurunan investasi langsung pada neraca pembayaran yang justru memberikan dorongan pemerintah untuk lebih meningkatkan investasi langsung dna diharapkan dapat menutup kenaikan defisit transaksi berjalan yang terjadi selama ini (Kementerian Koordinator Bidang Perekonomian RI, 2018).

Salah satu bentuk kebijakan dalam merespon fenomena tersebut yaitu diterbitkannya paket kebijakan ekonomi (PKE) XVI yang meliputi perluasan fasilitas pengurangan pajak penghasilan badan (tax holiday), merelaksasi daftar negatif investasi (DNI), dan meningkatkan devisa hasil ekspor (DHE) dari hasil sumber daya alam. Paket kebijakan ini mencakup permasalahan yang cukup komplek karena selain sebagai upaya peningkatan investasi, ini juga menjadi upaya untuk penciptaan lapangan kerja dengan adanya berbagai investasi masuk.

Upaya dalam meningkatkan dan menjaga ketahanan ekonomi nasional, dibutuhkan suatu kebijakan yang kuat dalam mengendalikan devisa negara dengan insentif perpajakan. Kebijakan pengendalian ini berupa kewajiban untuk memasukkan DHE dari ekspor khusus untuk bahan sumber daya alam berupa pemberian tarif final pajak penghasilan atas deposito, tabungan, serta diskonto dari Sertifikat Bank Indonesia sehingga devisa debagai penghasilan negara akan dipenuhi secara baik oleh perusahaanperusahaan ekspor terkait.

Selain itu, kebijakan lain yang secara kompleks dilakukan dalam rangka mengoptimalisasi pelaksanaan relaksasi dan keterbukaan bidang usaha diatur dalam Peraturan Presiden No. 44 Tahun 2016 terkait peningkatan daya tarik dan daya saing investasi bagi domestik maupun asing yang membawa teknologi, inovasi, efisien sekaligus perluasan bagi inovasi ekspor serta kemitraaan bagi UMKM dan koperasi 
(Media Keuangan, 2018). Data BKPM (Badan Koordinasi Penanaman Modal) menunjukkan perkembangan FDI yang terus meningkat meskipun pada kuartal ketiga 2018 sempat mengalami penurunan. Selama lima tahun terakhir, rata-rata FDI Indonesia mencapai 17,2 millar USD per tahun dengan peningkatan 1,2\% diatas negara ASEAN lainnya kecuali Singapura (Media Keuangan, 2018). Pada tahun 2018 juga terdapat dampak akibat dari kebijakan yang bersumber dari Peraturan Presiden No. 44 tahun 2016 yang ditunjukkan dengan peningkatan minat investasi PMA sebesar $108 \%$ dan PMDN sebesar 82,5\%. Hasil ini mengkonfirmasi bahwa kebijakan tersebut berlaku cukup efisien dan efektif dalam menarik investor baik dari investor asing maupun domestik.

Selain itu, diberlakukannya kebijakan DNI pada tahun 2018 ini juga berhasil memberikan dampak positif dalam meningkatkan daya tarik investasi. Selain itu kebijakan ini juga membawa dampak positif bagi pengembangan dan perluasan investasi UMKM dan Koperasi dimana sektor tersebut merupakan sektor penggerak ekonomi rakyat yang mayoritas dapat dijangkau. Hal ini mengakibatkan peningkatan investasi pada sektor UMKM dan koperasi ini cukup membawa dampak yang luas bagi peningkatan produktivitas bahkan penyerapan tenaga kerja. Kebijakan ini juga diharapkan dapat membantu pemerintah dalam memberikan solusi pada fundamental permasalahan yang dihadapi antara lain masalah defisit neraca pembayaran, perlambatan pertumbuhan dan ekspor, ketergantungan impor serta tingginya biaya logistik.

Terkait dengan investasi, menelaah struktur kelembagaan penanaman di Indonesia EoDB (Ease of Doing Business) sebagai salah satu standar internasional sebagai acuan para investor dalam melakukan usaha yang dikeluarkan oleh World Bank group setiap tahun sekali. Berdasarkan standart EoDB dari World Bank Grop, pada tahun 2018, Indonesia menempati peringkat ke 72 meningkat sebesar 19 peringkat dari tahun sebelumnya. Dalam kurun 6 tahun terakhir, Indonesia mengalami peningkatan kemudahan berbisnis yang sangat baik dari peringkat 129 menjadi 72 . Hal ini sebagai bentuk dari upaya pemerintah dalam membenahi tatanan kelembagaan sehingga memengaruhi tingkat kemudahan bisnis yang dituangkan dalam standar EoDB yang disimpulkan dari beberapa kriteria yang telah ditentukan.

Peringkat ini membawa pengaruh yang sangat positif bagi masyarakat karena kepercayaan investor pada Indonesia semakin meningkat sehingga akan membawa dampak baik bagi perekonomian dan penciptaan lapangan kerja. selain itu, kinerja yang baik dalam peringkat EoDB ini juga akan merubah orientasi investasi para investor yang semula hanya sebagai spekulasi menjadi investasi jangka panjang yang tidak hanya sesaat dilakukan sebagai motif spekulasi saja. Hal tersebut akan membantu akselerasi pada pertumbuhan dan pembangunan ekonomi Indonesia. Peningkatan investasi tersebut juga dapat berdampak pada penekanan angka pengangguran sebagai bentuk dari penciptaan lapangan kerja yang meluas dan menyerap tenaga kerja. Kondisi tersebut juga secara tidak langsung dapat mereduksi angka kemiskinan melalui peningkatan pendapatan per kapita masyarakat.

Upaya penyederhanaan proses bisnis serta perizinan dan persyaratan administrasi juga menjadi point penting dalam mendorong investasi yang semakin meningkat masuk. Upaya lain dalam meningkatkan EoDB sebagai upaya menarik daya minat investor juga dilakukan penyusunan regulasi pada bidang kepabeaan dan cukai, pengelolaan utang, perpajakan dan profesi jasa keuangan untuk mempercepat pelaksanaan kemudahan usaha (Media Keuangan, 2018).

Selanjutnya, hubungan variabel inflasi dan penyerapan tenaga kerja menunjukkan hubungan negatif signifikan yang dikonfirmasi dengan nilai koefisien sebesar -12077.32 dan nilai probabilitasnya sebesar 0,0036 yang lebih kecil dari $a=0,05$. Hasil ini berarti ketika terjadi kenaikan 12077.32, maka pe- 
nyerapan tenaga kerja mengalami peningkatan. Maka dapat disimpulkan bahwa inflasi menunjukkan negatif dan berpengaruh signifikan terhadap penyerapan tenaga kerja di Indonesia. Hasil ini sejalan dengan penelitian Hutagalung dan Sentosa (2013) bahwa tingkat inflasi mempunyai hubungan negatif terhadap penyerapan tenaga kerja. Kenaikan inflasi yang tidak terkendali dan tidak seimbangan dengan stabilitas perekonomian dalam waktu tertentu akan mengakibatkan kesenjangan pendapatan, penurunan dalam efisiensi ekonomi. Dalam hal ini inflasi menyebabkan investasi terfokus pada padat modal, dan mengabaikan padat karya sehingga meningkatkan jumlah pengangguran, dan juga menyebabkan perubahanperubahan didalam output dan penyerapan tenaga kerja dengan memotivasi perusahaan agar menyesuaikan output saat terjadi inflasi.

Inflasi dapat memberika efek negatif perekonomian ketika keberdaannya tidak terkendali. Hiperinflasi atau inflasi yang terlalu tinggi dapat mengakibatkan penurunan daya beli dan penurunan nilai uang. Harga yang terlampau tinggi dapat mengakibatkan krisis moneter seperti yang terjadi pada 1998 ketika inflasi mencapai 77\% pada 1998 dan mengakibatkan komponen perekonomian lain mengalami pelemahan yang besar, sehingga berkaca dari pengalaman tersebut, beberapa kebijakan moneter dan fiskal dilakukan untuk mengendalikan laju inflasi pada tingkat yang stabil (Suseno dan Astiyah, 2009).

Pengendalian inflasi ini diharapkan dapat mengendalikan harga dan menstabilkan harga. Sebab ketika inflasi yang terlalu rendah juga dapat mengakibatkan kelesuan perekonomian sebab harga-harga terlalu rendah. Pengendalian inflasi bertujuan mengendalikan harga yang disesuaikan dengan kondisi perekonomian dan daya beli masyarakat, bukan untuk menurunkan harga serendah mungkin. Sebab, tinggi rendahnya suatu inflasi bersifat sangat relatif dan berbeda dari kondisi perekonomian negara satu dengan yang lainnya. Pada mayoritas negara maju, tingkat inflasi yang rendah berada pada angka 2-3\%, sementara di Indonesia, angka inflasi kurang dari 10\% masih dianggap dalam tataran yang wajar. Menurut Dornbush dan Fischer (1993) mengklasifikasikan laju inflasi menjadi inflasi moderat (sedang), tinggi, sangat tinggi (ekstrem) dan hiperinflasi. Dimana hiperinflasi ini merupakan inflasi dengan tataran yang sangat tinggi dan tidak dapat terkendali sehingga perekonomian mengalami boom harga yang melambung dan mengakibatkan adanya krisis. Namun telah disepakati oleh seluruh dunia bahwa inflasi membawa dampak yang tidak baik bagi perekonomian sehingga harus dikenalikan dengan sinergi antara kebijakan moneter dan kebijakan fiskal (Suseno dan Astiyah, 2009).

Berdasarkan hasil analisis bahwa investasi dan ekspor yang berdampak positif terhadap penyerapan tenaga kerja di Indonesia ini juga dikonfirmasi dengan fenomena peninngkatan investasi dan nilai ekspor yang akhirnya memberikan peluang pada penciptaan lapangan kerja dan peningkatan produktivitas. Pada februari 2018, angkatan kerja sebesar 133,94 juta orang yang mengalami kenaikan sebesar 2,39\% dari februari 2017 ini juga direspon positif dengan peningkatan TPAK tingkat partisipasi angkatan kerja) sebesar 0,18\%. Kondisi ini mengkonfirmasi bahwa peningkatan angkatan kerja juga mampu diakomoditas dengan penciptaan lapangan kerja baru dengan ditunjukkan oleh nilai TPAK yang meningkat (Badan Pusat Statistik, 2018). Sementara itu, menjadi catatan positif juga bahwa dalam tahun 2018 juga terjadi penurunan angka pengangguran yang ditunjukkan dengan berkurangnya sebesar 140 ribu orang dan angka pada tingkat penganggurna terbuka sebesar 5,13\% pada februari 2018.

Selain itu, jumlah penduduk yang telah bekerja juga bertambah sebesar 2,53 juta jiwa selama tahun 2017-2018 yang mulanya berjumlah 127,07 juta orang. Sumber daya manusia yang terserap dengan baik oleh hadirnya berbagai lapangan kerja mengalami peningkatan yang signifikan. Mayoritas penyerapan tenaga kerja pada 2018 
berada pada sektor penyediaan akomodasi dan makan minum sebesar $0,68 \%$, jasa sebesar $0,40 \%$, dan industri pengolahan sebesar 0,39\% (Badan Pusat Statistik, 2018). Sementara itu, lapangan kerja pada sektor primer seperti sektor pertanian justru mengalami penurunan sebesar $1,41 \%$. Selain itu pada sektor kontruksi meningkat sebesar 0,20\% dan sektor jasa pendidikan meningkat sebesar $0,16 \%$. Mayoritas penduduk bekerja pada sektor informal sebanyak 73,98 juta jiwa atau berkisar $58,22 \%$. Namun penyerapan tenaga kerja pada sektor informal ini cenderung menurun sebesar $0,13 \%$ dibandingkan pada 2017.

Jumlah tenaga kerja yang terserap pada kategori lapangan kerja setiap sektor ini menunjukkan bahwa kemampuan penyerapan tenaga kerja dalam mengakomodir kemampuan sektor dalam merespon permintaan pasar dan penyerapan tenaga kerja sesuai yang telah diperhitungkan. Struktur pada penduduk yang bekerja menurut lapangan kerja pada februari 2018 masih didominasi oleh sektor utama yang menjadi basis dari komponen PDB antara lain pertanian, kehutanan dan perikanan sebesar $30,46 \%$ meskipun penyerapannya tenaga kerjanya mengalami penurunan. Kemudian sektor perdagangan besar sebesar 18,53\% dan industri manufaktur (industri pengolahan) sebesar $14,11 \%$. Berdasarkan tren lapangan kerja selama februari 2017 hingga februari 2018 menunjukkan bahwa lapangan usaha perdangan besar cukup mendominasi dari sub sektor penyediaan akoodasi dan makan minum, jasa lainnya dan industri pengolahan. Kinerja instrumen makroekonomi seperti upaya peningkatan investasi, ekspor serta pengendalian inflasi ternyata mampu menunjukkan dampak positif bagi peningkatan penyerapan tenaga kerja sehingga dapat menekan angka pengangguran dan kemiskinan yang selama ini menjadi masalah utama yang kerap kali terjadi.

\section{SIMPULAN DAN SARAN}

Hasil analisis penelitian ini menunjukkan bahwa FDI dan kinerja ekspor mem- berikan kontribusi positif signifikan terhadap penyerapan tenaga kerja di Indonesia. Hasil ini dikonfirmasi dengan nilai koefisien positif pada variabel FDI dan ekspor serta nilai probabilitas yang lebih kecil dari nilai alfa $5 \%$. Sementara itu, variabel inflasi menunjukkan kontribusi negatif signifikan terhadap penyerapan tenaga kerja di Indonesia yang ditunjukkan dengan nilai koefisien negatif dan nilai probabilitas lebih kecil dari nilai alfa 5\%. Berdasarkan dari hasil kesimpulan penelitian ini, maka peningkatan pembangunan infrastruktur untuk mempermudah mobilitas sehingga dapat menarik dan meyakinkan para investor untuk menanamkan modalnya di Indonesia. Selain itu, kemudahan perizinan perlu ditingkatkan melalui berbagai alternatif yang lebih efektif dan efisien untuk memperlancar jalannya administrasi perizinan investor. Selain itu, perlu adanya peningkatan kualitas sumber daya manusia agar mampu bersaing dan menghasilkan output yang berkualitas sehingga dapat meyakinkan investor dan dapat menahan kontribusi pada capital intensive sehingga lebih gencar investasi akan dialokasi pada labor intensive yang dapat menyerap tenaga kerja lebih besar. Dari sudut pandang moneter perlu adanya sinergisitas yang terus meneru harus dilakukan oleh pemerintah dan Bank Indonesia untuk menjaga stabilitas harga sehingga inflasi dapat terkendali dengan baik yang akan berdampak pada permintaan secara agregat yang dapat berpengaruh pada kesempatan kerja.

\section{DAFTAR PUSTAKA}

Agustini, Y. dan E. P. Kurniasih. 2017. Pengaruh Investasi PMDN, PMA, dan Penyerapan Tenaga Kerja Terhadap Pertumbuhan Ekonomi dan Jumlah Penduduk Miskin Kabupaten atau Kota di Provinsi Kalimantan Barat. Jurnal Ekonomi Bisnis dan Kewirausahaan 6(2): 97-119.

Appleyard, D., L. S. Cobb, dan A. Field. 2008. International Economics. McGraw-Hill Education. New York. 
Arsyad, L. 2010. Ekonomi Pembangunan. UPP STIM YKPN. Yogyakarta.

Badan Koordinasi Penanaman Modal. 2016. Penanaman Modal Asing Berdasarkan Sektor Ekonomi tahun 2009-2016. BKPM Indonesia.

Badan Perencana Pembangunan Nasional. 2016. Perkembangan Realisasi Investasi PMA Berdasarkan Laporan Kegiatan Penanaman Modal (LKPM) Menurut Lokasi. Bappenas Indonesia.

Badan Pusat Statistik. 2010. www.bps.go.id.

Badan Pusat Statistik. 2016. Nilai Tukar Rupiah Terhadap Dolar AS tahun 20092016. BPS Indonesia.

Badan Pusat Statistik. 2017. Ketenagakerjaan Indonesia. www.bps.go.id.

Bande, R. dan D. Riveiro. 2013. The Consumption-Investment Unemployment Relationship in Spain: an Analysis with Regional Data. Theoretical and Practical Research in Economic Fields 4.1(7): 5.

Bank Dunia. 2010. Doing Business 2010. World Bank Washington DC

Bank Indonesia. 2017. Laporan Perekonomian. www.bi.go.id.

Bank Indonesia. 2018. Laporan Perekonomian. www.bi.go.id.

Bank Indonesia. 2016. Laporan Perekonomian Indonesia. Bank Indonesia. Jakarta.

BP2KP. 2014. Laporan Akhir Kajian Penyusunan Target Ekspor Impor Indonesia 20152019. Pusat Kebijakan Perdagangan Luar Negeri Badan Pengkajian Dan Pengembangan Kebijakan Perdagangan Kementerian Perdagangan.

Chandra, O. 2006. Project Planning, Analyaia, Selection, Financing and Implementation and Review (6th edition). Mcgraw-Hill publishing Company Ltd. USA.

Çolak, O. dan N. Alakbarov. 2017. Does Foreign Direct Investments Contribute to Employment? Empirical Approach for The Commonwealth of Independent States. Bilig 83(2017): 147-169.

Craigwell, R. 2006. Foreign Direct Investment and Employment in the English and DutchSpeaking Caribbean. ILO Subregional Office for the Caribbean
Dharma, B. D. dan S. Djohan. 2015. Pengaruh Investasi Dan Inflasi Terhadap Kesempatan Kerja Melalui Pertumbuhan Ekonomi Di Kota Samarinda. Kinerja 12(1).

Dinh, T. T. H., D. H. Vo, dan T. C. Nguyen. 2019. Foreign Direct Investment and Economic Growth in the Short Run and Long Run: Empirical Evidence from Developing Countries. Journal of Risk and Financial Management 12(4): 176.

Dornbusch, R. dan S. Fischer. 1993. Macroeconomics. Mcgraw-Hill College. USA.

Friedman, M. 1968. The Role of Monetary Policy. The American Economic Review 58(1).

Gozgor, G. 2018. Does the structure of employment affect the external imbalances?Theory and evidence. Structural Change and Economic Dynamics 45(2018): 77-83.

Greenaway, D., W. Morgan, dan P. Wright. 2002. Trade liberalisation and growth in developing countries. Journal of Development economics 67(1): 229-244.

Greene, W. H. 2012. Econometric Analysis Sevent Edition. Prentice Hall. New York.

Hady, H. 2001. Ekonomi Internasional Teori dan Kebijakan Keuangan Internasional. Buku 2. Ghalia Indonesia. Jakarta.

Hutagalung, P. S. P. dan P. B. Santosa. 2003. Analisis Pengaruh Upah Minimum dan Inflasi erhadap Kesempatan Kerja Sektor Industri Pengolahan Besar dan Sedang di Jawa Tengah (35 Kab atau Kota). Diponegoro Journal of Economics 2(4): 1-12.

Internasional Monetary Fund. 2010. Finance and Development, Point of View: Asia: A Perspektive on the Subprime Crisis

Junaidi, Z. 2016. Analisis Kondisi dan Proyeksi Ketenagakerjaan di Provinsi Jambi. Jurnal Perspektif Pembiayaan dan Pembangunan Daerah 3(3): 141-150.

Kemenkeu. 2013. Kementerian Keuangan Republik Indonesia. www.kemenkeu.go.id.

Kementerian Koordinator Bidang Perekonomian Republik Indonesia. 2018. PAKET KEBIJAKAN EKONOMI Minggu 
ke-III November 2018 (Tahap XVI). Jakarta, 16 November 2018.

Kuncoro, H. 2012. Upah dan Sistem Penyerapan Tenaga Kerja. Penerbit Media. Jakarta.

Laporan Perekonomian Bank Indonesia. 2018. www.bi.go.id.

Laporan Perekonomian Indonesia. 2017. Bank Indonesia. www.bi.go.id.

Litbang Perdagangan. 2013. Kementerian Perdagangan Republik Indonesia. www. kemendag.go.id.

Matthew, O. dan A. Johnson. 2014. Impact of Foreign Direct Investment on Employment Generation in Nigeria: A Statistical Investigation. IOSR Journal of Business and Management 16(3): 44-56.

McMillan, M. S. dan D. Rodrik. 2011. Globalization, Structural Change and Productivity Growth. National Bureau of Economic Research Working Paper 17143.

Media Keuangan. 2018. Transformasi Informasi Kebijakan Fiskal Pangkas Regulasi, Permudah Investasi. Volume XIII/ No. 128/Mei 2018.

Mupfawi, J. dan Z. Tambudzai. 2015. Impact of Foreign Direct Investment on Employment in Zimbabwe. Economic Integration, Entrepreneurship and Sustainable Development Conference: 1-23.

Outlook Worldbank. 2017. www.worldbank. org.

Phelps, E. S. 1968. Money Wage Dynamics and Labour Market Equlibrium. The Journal of Political Economy 76(4): 678-711.

Phillips, A. W. 1958. The Relationship Between Unemployment and the Rate of Change of Money Wage Rates in The United Kingdom. Economica 25(100): 283-299.

Rizvi, S. Z. A. dan M. Nishat. 2009. The Impact of Foreign Direct Investment on Employment Opportunities: Panel Data Analysis "Empirical Evidence from Pakistan, India and China". The Pakistan Development Review: 841-851.

Sukirno, S. 2010. Makroekonomi, Teori Pengantar. Edisi Ketiga. PT. Raja Grasindo Perseda. Jakarta.
Sandika, R. S., Y. Maulida, dan D. Setiawan. 2014. Pengaruh Investasi Terhadap Penyerapan Tenaga Kerja Di Kabupaten Pelalawan. Jurnal Online Mahasiswa (JOM) Bidang Ilmu Ekonomi 1(2): 1-16.

Sidki, H. 2016. Pengaruh Penanaman Modal Asing Langsung Terhadap Penyerapan Tenaga Kerja Di Indonesia Tahun 19862014. Skripsi. Universitas Gadjah Mada. Yogyakarta.

Silvia, E. D., Y. Wardi, dan H. Aimon. 2013. Analisis Pertumbuhan Ekonomi, Investasi, dan Inflasi di Indonesia. Jurnal Kajian Ekonomi 1(2).

Simanjuntak, P. J. 1998. Pengantar Ekonomi Sumber Daya Manusia. Lembaga Penelitian FE UI. Jakarta.

Sjöholm, F. 2016. Foreign Direct Investment and Value Added in Indonesia. IFN Working Paper No. 1141.

Sriwardiningsih, E. 2010. Dampak Penularan Krisis Global Terhadap Aliran Investasi Asing di Indonesia. The Winners 11(2): 130-140.

Suseno, dan S. Astiyah. 2009. Inflasi. Seri Kebanksentralan No 22. Pusat Pendidikan dan Studi Kebanksentralan Bank Indonesia. www.bi.go.id.

Tambunan, T. 2001. Industrialisasi di Negara Sedang Berkembang. Gharia Indonesia. Jakarta.

Todaro, M. 2000. Ekonomi Untuk Negara berkembang Suatu Pengantar Tentang Prinsip dan Kebijakan Pembangunan. Edisi Ketiga. Bumi Aksara. Jakarta.

Todaro, M. P. dan S. C. Smith. 2003. Pembangunan ekonomi di dunia ketiga. Erlangga. Jakarta.

Undang-Undang Nomor 11 Tahun 1970 tentang Penanaman Modal Asing. www. jdih.kemenkeu.go.id.

Undang-Undang Republik Indonesia Nomor 1 Tahun 1967 Tentang Penanaman Modal Asing dan dilengkapi serta disempurnakan oleh Undang-Undang Republik Indonesia Nomor 11 Tahun 1970 juga tentang Penanaman Modal Asing.

Undang-Undang Republik Indonesia Nomor 13 Tahun 2003 Tentang Ketenagakerjaan. 
UU Pasal 1 No. 25 tahun 2007 tentang Penanaman Modal. http://www.jdih. kemenkeu.go.id/fullText/2007/25TAHUN2 007UU.htm

Vanda, N. 2008. Penanaman Modal Asing Dan Penyerapan Tenaga Kerja Di Sektor Industri. Pusat Penelitian KependudukanLembaga Ilmu Pengetahuan Indonesia (PPK-LIPI). III(2).

Wibowo, T. 2013. Dampak Penurunan Ekspor Terhadap Penyerapan Tenaga
Kerja. Buletin Ilmiah Litbang Perdagangan $7(2)$.

World Economic Outlook April 2009. International Monetary Fund. www. imf.org.

World Economic Outlook Database. 2010. www.worldbank.org.

Worldbank. 2017. www.worldbank.org.

Sumpena, N. A. F. 2018. Pengaruh Liberalisasi Perdagangan Terhadap Penyerapan Tenaga Kerja di Indonesia. Skripsi. Institut Pertanian Bogor. 